\title{
THE CONTRIBUTION OF CSR PROGRAM IN BUILDING COMMUNITY RESILIENCE THROUGH DEVELOPMENT OF COMMUNITY ENTERPRISES
}

\author{
Amirul Mustofa ${ }^{a}$, Novi Indah Sri Rahayu ${ }^{b}$ \\ ${ }^{a}$ Lecturer in Public Administration Studies Program \\ ${ }^{\mathrm{b}}$ Alumni from the Public Administration Science Program \\ Dr. Soetomo University - Surabaya Indonesia \\ amirul.mustofa@unitomo.ac.id; and noviindahsrirahayu@gmail.com
}

\begin{abstract}
This article aim to analyze the contribution of CSR programs for Development of Micro, Small, and Medium Enterprises (MSMEs) from the community. The CSR program implementers who are responsible for developing community business in this discussion are East Java business development institutions. Business development programs, through stages: training and assistance, financing facilitation, and marketing. The ultimate goal of this business development program is to create MSMEs have a positive impact on the development of individual and community businesses. The method of approach used is qualitative. Data collection through documentation, interviews, and observation. The results of the study show that first, the development program of MSME from the community has a positive impact on business development. However, the weakness of this program is that assistance to improve the product marketing model still needs to be optimized. the hope is that some goods produced, have a competitive sale value on the market; and second, facilitation of CSR programs to facilitate prospective business communities who have attended educational programs is very necessary, especially to be able to get access to funds to banking institutions.

Keywords: Corporate Social Responsibility, Development of Micro, Small, and Medium Enterprises
\end{abstract}




\section{Introduction}

Development of Community Enterprises

MSMEs are productive businesses that are owned by individuals or business entities that are not medium or large corporate branches. in practice, MSMEs has its strength, even though the country is experiencing an economic crisis, even able to make a positive contribution to economic growth. The study conducted by Tamer et. al in the Middle East, which is based on several expert opinions, shows that MSMEs have a very important role in economic growth and contribute to job creation (Tamer et.al 2018: 166). In detail, Tamer et.al have formulated of the results of the study as intended that micro and small businesses have contributed to: (i) economic development of a country, especially in a country classified as developing countries (Mead and Liedholm (1998); (ii) export development and reducing the balance of payments deficit due to its ability to access foreign markets with a variety of products (Jawad, 2006); (iii) job creation, increased productive employment opportunities, and regional development, where business is spread in all regions with flexible character, and the use of simple technology (Omar, 2006); and (iv) able to prevent migration flows (Saleh, 2005).

Such conditions are not different from in Indonesia, that MSMEs have an important role, especially in opening new jobs and reducing unemployment. Therefore, it is very appropriate if the government continues to pay attention to these business people in the form of regulations. The development of MSMEs is determined through Government Regulation No. 17/2013, which is an elaboration of Law No. 20/2008 concerning MSMEs. One of the positive impacts of this regulation is that MSMEs growth has improved. Sidoarjo Regency is the district that has the most MSMEs in Indonesia. Therefore, Sidoarjo Regency was given the attribute as "Indonesian MSMEs City". MSMEs data from the East Java Central Bureau of Statistics show that in 2008 there were 4.2 million MSMEs; then in 2012 it rose to 6.8 million; in 2018 it (jumped to 9.59 million (https://memontum.com/50616-pertumbuhan-membludak-206-000-ukm-sidoarjo-

didorong-jadi-ikm). The CSR program implementers for the development of MSMEs in PT. Astra International, Tbk., is a Business Development Institute (BDI/LPB)led by the Dharma Bhakti Astra Foundation (DBAF/YDBA). Meanwhile, for the LPB that the development of MSMEs is one of the targets of its CSR program because MSMEs have not been able to develop properly to run their businesses, due to limited financial resources and low skills of their workforce. In connection with the rationale above, this article aims to analyze the contribution of CSR programs carried out by the LPB in developing MSMEs.

\section{REVIEW THEORY}

\section{Escalation of the Corporate Social Responsibility Concept}

The concept of social responsibility created by Howard R. Bowen (1953), with the statement that "every property owner must be responsible to God and the community" is a concern for property owners, especially company managers. Furthermore, this statement becomes the company's reference for formulating policies in the field of social responsibility (CSR), aimed at social interests and environmental degradation. These changes and innovations were then followed by several experts including Wood (1991), and Carroll (1999 and 2008). Some experts named Bowen as the " founder of modern 
Development of Community Enterprises corporate social responsibility "(Pascal Gond and Moon, 2011: 6). Discussed the concept of CSR, then developed, so Elkington (1997) formulated his famous concept" triple bottom line "in the book" Cannibals with Forks, triple bottom line Twentieth Century Business ". They say that if a company wants to maintain it needs to pay attention to three things, yes that: profit, people, and the planet. participate according to the citizenship autonomy (participation); work together to identify and take action, and build networks between community organizations (collaboration); and have the ability to claim their human rights, fulfill their needs and have greater control over the decision making a process that can affect their lives (social justice).

Escalation of CSR concepts, grouped by Amirul et al. (1996) into 5 groups, namely: First, Epstein (1987), Carroll (1979), and McWilliams \& Siegel (2001) use the term CSR which is oriented towards the voluntary improvement of social and environmental conditions. The form of company programs such as: giving compensation to the poor, training that aims to improve community skills so that they have empowerment in the economy and improve community status, as well as creating a more conducive environment around the company to support company development. Second, Frederick (1986) uses corporate social rectitude terms, Frederick (1978), uses the term of corporate social responsiveness, and Wood (1991) uses the term of corporate social performance. This second classification, CSR programs are oriented to creating conducive conditions in the corporate environment, so that the implementation of the company's work program plan is not disturbed by negative shocks that occur in the corporate environment. When companies pay attention to this conditioning program, it can be sure to have a positive impact on the progress of company performance.

Third, Maignan \& Ferrell (2000), and Matten \& Crane (2005) use the term corporate citizenship. CSR programs are oriented towards the interests of citizens who are considered to have a positive impact on company performance. The company is expected to be able to meet the needs of citizens for goods and services, which are usually carried out by the Government. Fourth, Clarkson (1998), Frooman (1999), Campbell (2006), Crouch (2006), and Basu \& Plazzo (2008) use the term corporate stakeholders. The CSR program is intended for the benefit of internal and external stakeholders. Corporate concern for the company's external and internal conditions is reinforced by Clarke (2004: 2 ), namely that corporate governance is concerned with maintaining a balance between economic and social goals and between individual and communal goals. Fifth, the European Commission (2001) uses strategic corporate social responsibility terms, and Scherer \& Palazzo (2011), uses the term of political corporate social responsibility. Terminology was established by the European Commission (2001), seeks to encourage companies to establish CSR programs into the company's strategic plan. Then the establishment of this kind of CSR program was developed by Scherer \& Palazzo (2011), to encourage companies to implement CSR programs as strategic programs in the company and implement CSR programs that are in synergy with government development programs. 


\section{Community Empowerment}

Mardikanto (2014: 156) quoted Sumodiningrat's view that community empowerment is defined as "the ability of individuals together with the community to make the community empowered." This definition means that there are efforts to provide strength or reinforcement to the community. Thus empowerment is a series of activities to empower groups vulnerable and weak in society, including the poor, so they can meet their physical, economic and social needs. Shardlow (1998: 32) defines empowerment "the process of controlling centrally the lives of people who are weak and powerless so can shape their future ". The essence of this definition is an effort to formulate how individuals or groups of people can control their own lives and have the power to shape their future according to their wishes. Fr Iedman (1992), gives a rather different definition, community empowerment is the process of providing the capacity to the community in solving problems of poverty and environmental sustainability.

Empowerment is an alternative program in development programs that are centered on people and the environment. Shaw (2007: 2), explains that Community Empowerment (CE) is the result of placing the real value of community development (CD). There are five real values of CDs, namely: learning, equality, participation, cooperation, and social justice. The five-CD values embedded in $\mathrm{CE}$ are how people can understand and realize: their skills, knowledge, and expertise so they can contribute to themselves. The output of the learning process is to produce people who are able to place themselves in other communities, especially to reduce various types of oppression (equality); has the ability to participate in accordance with the citizenship autonomy (participation); work together to identify and take action, and build networks between community organizations (collaboration); and have the ability to claim their human rights, fulfill their needs and have greater control over the decision making process that can affect their lives (social justice).

The concept of $\mathrm{CD}$ has become more developed when companies take part in contributing to their CSR programs in development programs. The involvement of companies and the private sector in the CD program in 2000, led by the United Nations which is a representation of the private sector has been committed to supporting sustainable of development and the creation of good corporate citizenship. The concept of CSR is then adapted into corporate citizenship, which is a perspective, attitude, and behavior of the company when dealing with other parties, for example, customers, suppliers, society, government and other stakeholders. The purpose of corporate citizenship is as a way to improve the company's reputation, increase competitive advantage and help improve the quality of human life. Specifically corporate citizenship aside from paying attention to the issue of $\mathrm{CD}$, protection and environmental preservation also, provide access to $\mathrm{CE}$.

The $\mathrm{CD}$ is a major component of the concept of corporate citizenship. This means that if the CD program is carried out by the company as well as possible, there will be a harmonious relationship between the company and the surrounding community. The community feels benefited by the existence of companies operating in their environment. Through $\mathrm{CD}$, it is expected that there will be a redistribution of responsibility and 
Development of Community Enterprises authority, as well as a change of power (Gunawan and Yani, 2003: 45). The CD program has three main characters, namely: community-based, resource-based, and sustainable. The goals to be achieved on the CD are community capacity and welfare. The first goal is community capacity can be achieved through efforts to empower community members to participate in the production process or supporting institutions in the production process, equality by not distinguishing status and expertise, security, sustainability, and cooperation, all of which run simultaneously. The second goal, if the community has been able to understand all the potential that is owned and able to implement, then the welfare will be achieved.

\section{RESEARCH METHOD}

This study uses a qualitative approach. Qualitative research according to Patton (1990) is carried out through: first, data collection that is not limited by predetermined categories; second, provide depth and detail through direct quotations and careful descriptions of program situations, events, people, interactions and observed behaviors, and third, open question formats without any attempt to match program activities or people's experiences into things that already discussed before. The focus of this research is on the LPB-Waru program for the development of MSMEs that are assisted. Data was collected through interviews with informants and documents that had been carried out by LPB-Waru and MSMEs partners. Data are analyzed interactively as the theories of Miles, Huberman, and Saldana (2014).

\section{DISCUSSION}

YDBA is a foundation owned by Astra International Group which was founded in 1980. YDBA's establishment aims to help improve technical, management, marketing, financing, and information technology skills to MSMEs. Implementation of this goal in the regions, YDBA and Astra Group established the LPB, one of which is LPB-Waru, located in Waru, Sidoarjo Regency of 18 LPBs in Indonesia. Until now, LPB-Waru has built 10,894 MSMEs and created 68,030 jobs through MSMEs development programs. Some training programs carried out by LPB, consisting of: subcontracted MSMEs related to Astra's business value chain, manufacturing MSMEs not related to Astra's business, Honda partner workshops, Astra Honda Authorized Service Station (AHASS), fourwheeled general workshops, two-wheel general workshops, craftsmen, and farmers. The results of research on the MSME development program by LPB-Waru in training and assistance activities; and facilitation can be formulated into five points, namely:

First, training and assistance of 5R. The results of the interview show that "the MSME development program with training and assistance methods of 5R (save, trim, clean, care, and diligent) greatly influences the development of their business, starting from the neatness of the place of business, maintenance, cleanliness, and sustainability customer". The performance of MSMEs built with the 5R culture, made customers more trustworthy, including collaborating with MSMEs that were guided by LPB-Waru. The growing sense of trust from customers and feeling satisfied with the services provided by MSMEs after receiving $5 \mathrm{R}$ training and assistance finally affected the increase of MSME 
Development of Community Enterprises turnover. Based on these data shows that the $5 \mathrm{R}$ training and assistance carried out by LPB to independent MSMEs shows that the program can not only increase the company's turnover, it also makes it's business a program that safeguards the environment by the direction of the CSR program while improving the quality of sustainable business. The results of this study are consistent with the concept of CSR as stated by Maignan \& Ferrell (2000), and Matten \& Crane (2005), where the concept of CSR is important for citizen development which in turn will have an impact on the importance of increasing company performance. Likewise, Clarke (2004) also emphasizes that the concept of CSR is more concerned with balancing between economic and social goals, as well as increasing individual businesses or MSMEs.

Second, training and assistance of K3L. The results of the research on training and assistance of the health, work safety and the environment $(\mathrm{K} 3 \mathrm{~L})$ program provided by LPB-Waru for MSMEs were aimed at improving employee performance to improve employee performance paying attention to and maintaining health, environmental safety. This program aims to protect workers, co-workers, families of workers, consumers, and other people related to work and work environment so that they remain safe at all times. MSMEs who are trained after participating in training and mentoring programs for K3L programs can improve their business performance well and can even reduce unwanted risks. The K3L program, if associated with the CSR program of LPB-Waru, is the implementation of the People Roadmap which is part of the Strategic Triple-P Roadmap, which has been implemented since 2011. The training and assistance program implemented by the Strategic People Roadmap is a program that is by the people development program of the Elkington Triple Bottom Line that is cited by Amirul (2016).

Third, training and assistance of financial management. The results of research on training and assistance in the field of financial management provided by LPB-Waru for MSMEs are intended to equip MSMEs employees and owners to understand good financial management systems and by standards. The financial management process in question is a process for managing the administration of the exit and entry of funds, including the process of planning, controlling, and financial reporting. The training and assistance program in the field of financial management provided by LPB-Waru is expected to be able to help fostered partners, to be able to manage their business turnover independently. Based on the findings of the study, the existence of training and assistance program in the field of financial management shows the success of MSME managers to reduce financial mismanagement, so that profits can be increased. This program is a Roadmap Portfolio program that is part of the Strategic Triple-P Roadmap in increasing MSME business. Thus when MSMEs can manage finances well, MSMEs become increasingly empowered or confident as stated by Shaw (2007). Furthermore, when the MSMEs that become the target become developed, PT. Astra International which launched the CSR program and implemented by LPB-Waru will get a positive impact, as stated by Scherer \& Palazzo (2011) with the strategic concept of CSR.

Fourth, financing facility. Financing facilities carried out by LPB-Waru to MSMEs, by bringing together MSMEs with Bank or Cooperative institutions. At the time of this research, financial institutions were prepared by LPB-Waru from PT Bank Permata, Tbk., and PT. Astra Mitra Ventura, and other microfinance institutions. 
Financing as intended is used by MSMEs for business development in the form of investments: buildings, equipment, and working capital. Precisely what the facilitation program is carried out in MSMEs Gathering activities with financial institutions. While financing facilitation is carried out with PO invoice financing, profit sharing, working capital, and investment. Through this program, MSMEs will later have independence in carrying out cooperation with Bank institutions. Power in this context by Shaw (2007) is interpreted as being able to collaborate and take action and build networks between community organizations. This kind of financing facilitation program will improve business performance. Furthermore, when business performance develops, it is expected that these MSMEs will become increasingly responsive to the environment as a concept of corporate social performance, formulated by Wood (1991).

Fifth, marketing facility. The marketing facilitation program provided by LPBWaru to MSMEs fostered partners, by holding a market facilitation program. One of the market facilitation programs carried out by LPB-Waru, namely by bringing together MSME partners who have leading sectors in manufacturing. When this research was conducted, data was obtained that three companies had production whose quality had standards, namely: PT. Elang Jagad, UD. KS Pro, and UD. Karya Jaya. The three companies were then asked to become Sub-con of PT. Rahmat Perdana Adimetal which is the first tier of AHM. Also, marketing facilities are provided through activities: exhibitions, and internet marketing. The marketing facilities through the exhibition include GIIAS (Gaikindo Indonesia International Auto Show), and Astra Workshop Development Association. The internet marketing facilitation program carried out by LPB-Waru aims to promote goods that have been produced by the assisted MSMEs. Through this program, LPB-Waru with its CSR program will be able to help MSMEs to save and develop their business sustainability as stated by Roosita (2005).

\section{CONCLUSION}

The MSMEs development program, which was carried out by LPB-Waru in the form of activities: training and mentoring, financing facilities, and marketing facilities, produced very positive benefits, especially to improve the performance of assisted SMEs. who pay more attention to conditions: people, planet, and environment; and second, the CSR program implemented by LPB-Waru in the effort to develop MSMEs, resulted in good business development. The MSME development program in the form of training and assistance, as well as facilities with various types, has a positive impact. The positive impact in question is: increasing its business, increasing income, increasing employee safety and welfare, increasing customer service. Thus, the MSME development program developed through CSR programs will be able to increase the income of business people and the income of the community around the company, so that it becomes part of the formation of community resilience in the community. 
Web Jurnal Online: jurnal.unmuhjember.ac.id

By: Amirul Mustofa; Novi Indah Sri Rahayu

The Contribution of CSR Program in Building Community Resilience Through

VI. REFERENCES

Development of Community Enterprises

Amirul, Mustofa. Bambang, Supriyono. Abdul Hakim, and Andy, Fefta Wijaya. 2016. International journal of management and administration science (IJMAS). Vol 3. page: 35-45. Publication date: 2016/3: www.ijmas.org

Bowen, H, R. 1953. Social Responsibility of the Businessman. Harper \& Row. New York. https://www.worldcat.org/title/social-responsibilities-of-the-businessman/oclc/ 229633

Elkington, John. 1997. Cannibals With Forks: The Triple Bottom Line of 21st Century. Business Capstone Publishing Limited. Oxford Centre for Innovation. Mill Street. Oxford OX2 OJX. The United Kingdom. https://www.ebah.com.br/content/ ABAAAgYmwAE/ cannibals-with-forks-thetriple-bottom-line-of-21 st-century-business-0865713928-1

Friedmann, J. 1992. Empowerment: The Politics of Alternative Development. Oxford: Blackwell.

Gunawan, Widjaja dan Yani, Ahmad, 2003, Hukum Tentang Perlindungan Konsumen, Gramedia Pustaka Utama, Jakarta.

Mardikanto, Totok dan Soebiato, Poerwoko. 2014. Pemberdayaan Masyarakat dalam Perspektif Kebijakan Publik. Edisi Revisi. Bandung: Alfabeta https://openlibrary. telkomuniversity.ac.id/home/catalog/id/99363/

Miles, Matthew B., Huberman, A. Michael, and Saldaña, Johnny. 2014. Qualitative Data Analysis: A Methods Sourcebook. Third edition. Sage Publications.

Pascal Gond, Jean, and Moon, Jeremy. 2011. "Corporate Social Responsibility in Retrospect and Prospect: Exploring the Life-Cycle of an Essentially Contested Concept (Introduction to Jean-Pascal Gond and Jeremy Moon (eds): Routledge Major Work on Corporate Social Responsibility)". International Centre for Corporate Social Responsibility Nottingham University Business School Nottingham University. No. 59-2011 ICCSR Research Paper Series - ISSN 1479-5124..

Patton, M, Q. 1990. Qualitative Evaluation and Research Methods (2nd ed.). Newbury Park. CA: Sage Publications, Inc.

Roosita, Hermien. 2005. Pemberdayaan Masyarakat dalam Pengelolaan Lingkungan Hidup pada Sektor Industri. Deputi Bidang Pengendalian Dampak Lingkungan Sumber Institusi Kementerian Lingkungan Hidup - 2005 http://www.google.co.id/ URL?sa=t\&rct=j\&q=community+development

Shardlow, Steven. 1998. "Values, Ethnic and Social Work", in Adam Robert, Lena Dominelli and Malcolm Pyne (eds). Social Work Themes, Issues and Critical Debates. London: MacMillan Press Ltd.

Shaw, Sue. 2007. "What is Community Development". Research Paper. Community Development Exchange Foundation. The UK.

Tamer, G., I., Mansour. Khairy, H., Eleshmawiy. Mahmoud, A., Abdelaziz. and Salah, S. Abd El-Ghani. 2018. "The Role of Small and Medium Enterprises in Economic Development, Case of Egypt". The International Journal of Business Management and Technology. Volume 2. Issue 5. September-October 2018. ISSN: 2581-3889 https://www.academia. edu/37657830/ 